Polymer Journal, Vol. 39, No. 12, pp. 1319-1327 (2007)

(C) 2007 The Society of Polymer Science, Japan

\title{
Grafting of Flax Fiber (Linum usitatissimum) with Vinyl Monomers for Enhancement of Properties of Flax-Phenolic Composites
}

\author{
B. S. KAITH ${ }^{\dagger}$ and Susheel KALIA \\ Material Science Laboratory, National Institute of Technology (A Deemed University), Hamirpur-177 005 (H.P.) India
}

(Received June 12, 2007; Accepted August 6, 2007; Published October 16, 2007)

\begin{abstract}
Binary vinyl monomers such as methylmethacrylate (MMA)/Ethylacrylate (EA), MMA/Acrylonitrile (AN) and MMA/Acrylic acid (AA) have been graft co-polymerized onto flax fibers under the influence of microwave radiations (MWR). Various reaction parameters have been optimized and maximum grafting (25\%) was observed in reaction time of $30 \mathrm{~min}$ at $210 \mathrm{~W}$ microwave power. Flax-g-copolymers thus prepared were used as reinforcing material in the preparation of flax-phenolic composites. Wear resistance was maximum with reinforcement of Flax-gpoly(MMA/AA). Composites reinforced with Flax-g-poly(MMA/EA) showed better tensile strength and can bear load upto $225 \mathrm{~N}$ with extension of $3.28 \mathrm{~mm}$ and composites reinforced with Flax-g-poly(MMA/AA) showed better compressive strength and can bear load upto $1000 \mathrm{~N}$ with compression of $1.74 \mathrm{~mm}$. Maximum values of MOR, MOE and SP were found to be $108.0 \mathrm{~N} / \mathrm{mm}^{2}, 5295.62 \mathrm{~N} / \mathrm{mm}^{2}$ and $99.29 \mathrm{~N} / \mathrm{mm}^{2}$ for the composites reinforced with Flax-g-poly(MMA/AA). On grafting of flax fibers with vinyl monomers, fibers become more and more moisture retardant. It has been found that strength of Flax-g-copolymers was found more than that of raw flax fibers. Flax-g-poly(MMA/ AA) has been found to show good thermal stability in comparison to other graft co-polymers and raw flax fibers. Phenol-formaldehyde (PF) composites reinforced with graft co-polymers of flax fibers showed better mechanical properties in comparison to composites reinforced with raw flax fibers. Composites reinforced with Flax-g-poly(MMA/AA) showed the increased values of MOR, MOE and SP. [doi:10.1295/polymj.PJ2007073]

KEY WORDS Flax / Graft Copolymerization / Phenol-formaldehyde / Composites / MOR / MOE / SP /
\end{abstract}

Graft copolymerization is one of the best methods for modifying the properties of natural polymers. Different binary vinyl monomer mixtures have been graft copolymerized onto cellulosics material for modifying the properties of numerous polymer back-bones. ${ }^{1}$ Modifying the properties of natural polymers through graft copolymerization has been reported by various workers. $^{2-12}$

The conventional technique of grafting and chemical modification of natural fibers requires significant time and energy. The use of MWR technique to modify the properties of natural fibers within the textile industry, although somewhat slow and still rather limited, is finding its way into numerous uses in production plants. ${ }^{13}$ Microwave radiation technique reduces the extent of physico-chemical stresses to which the fibers are exposed during the conventional techniques. ${ }^{12}$ Properties of natural fibers treated under MWR technique are same or even better than those of fibers modified through conventional techniques. ${ }^{13,14}$ Singh et al. ${ }^{15,16}$ have graft copolymerized the polyacrylamide onto chitosan and guar gum using MWR technique and found that maximum grafting was observed in very less time.

In recent years, polymer composites reinforced with natural fibers have received considerable attention both in literature and industry. Cellulose fibers have attracted the attention of scientist and technologist for energy-intensive applications, since these fibers are strong, light weight, abundant, renewable, nonabrasive, non-hazardous and inexpensive. The reduced tear and flexibility of processing machinery with no health problems make these fibers excellent reinforcing materials for plastics. ${ }^{17}$ Composites reinforced with natural fibers have several advantages over traditional material reinforced composites. ${ }^{18-20}$ Moisture causes degradation of mechanical properties of composites reinforced with natural fibers to a larger extent in comparison to composites reinforced with synthetic fibers, as a consequence of the higher moisture sorption behaviour and the organic nature of natural fibers. ${ }^{21,22}$ In order to develop composites with better mechanical properties and environmental performance, it becomes necessary to increase the hydrophobicity of the natural fibers and to improve the interface between matrix and natural fibers. There are number of methods to obtain these improvements such as graft copolymerization, esterification, silane treatment, plasma treatment and other chemical treatments. Only few workers have reported the use of graft copolymers as reinforcing material in the preparation of composites. Kaith et al. ${ }^{23-26}$ have reported the reinforcement of plastics with graft copolymers of flax fibers and it has been found that composites re-

${ }^{\dagger}$ To whom correspondence should be addressed (E-mail: bskaith@yahoo.co.in; kaith@nitham.ac.in). 
inforced with graft copolymers of flax fibers showed better mechanical properties. Mechanical properties of composites reinforced with acrylate grafted henequen cellulosics fibers were studied and found that best results obtained with poly(MMA) grafted cellulose fibers because of better fiber-matrix adhesion. ${ }^{27}$

Since the use of graft copolymers of natural fibers as reinforcement for plastics is meagerly reported and flax fibers are rich source of cellulose and are expected to provide an excellent material for their use in the preparation of phenol-formaldehyde composites. So, in the present paper, we report the preparation of composites from graft copolymers of flax fibers using phenol-formaldehyde as the binding material.

\section{EXPERIMENTAL}

\section{Materials and Methods}

Natural flax fibers (Linum usitatissimum) were supplied by Department of Agronomy, CSK HP Agriculture University, Palampur (India). Phenolic resin (resole) was prepared by the reaction of phenol ( $\mathrm{s} d$ fine-chem ltd., India) and formaldehyde (CDH, India) in material science laboratory. ${ }^{25}$ The specific absorption bands in the IR spectrum of the phenolic resin confirm the presence of its typical structural components. They are as follows: aromatic ring, 1594-1605 $\mathrm{cm}^{-1}$; hydroxyl groups, $3306 \mathrm{~cm}^{-1}$; hydroxyl groups connected with phenyl ring, $1229.4 \mathrm{~cm}^{-1}$; hydroxymethyl groups, $993-1023 \mathrm{~cm}^{-1}$; methylene linkages, 2873-2959 and 1456-1473 cm; ether linkages, 1069 $\mathrm{cm}^{-1}$. The chemical structure of the phenolic resin (average molecular weight of about $457 \mathrm{~g} / \mathrm{mol}$ ) is also confirmed by ${ }^{1} \mathrm{H}$ NMR and ${ }^{13} \mathrm{C}$ NMR spectrum, where are indicated the chemical shifts corresponding to the protons from relevant structural segments. ${ }^{28-30}$

Soxhlet extraction of the flax fibers with acetone was carried-out for $72 \mathrm{~h}$. Monomers were washed with $5 \%$ sodium hydroxide followed by water and were dried over anhydrous sodium sulphate. The dried monomers were distilled and the middle fraction was used. Composites were prepared in Compression Molding Machine (SANTEC India Ltd.). Libror AEG-220 (Shimadzu make) electronic balance was used for weighing purpose.

IR spectra of the samples were recorded with $\mathrm{KBr}$ pellets on Bomem, Hartmann \& Braun (MB-Series) Spectrophotometer. Scanning electron microscopic analysis of the flax and its graft co-polymers were carried-out on Electron Microscopy Machine (LEO 435 VP). Thermo gravimetric analysis and differential thermal analysis studies were carried-out in air on a thermal analyzer (LINSEIS L-81 11) at the heating rate of $10^{\circ} \mathrm{C}$ per minute.

Strength of fibers was measured with Stelometer
(MAG, FO501). Wear-resistance testing of the composites was carried-out on Wear \& Friction Monitor (DUCOM, 20LE). Tensile and Compressive strength of samples were tested on Universal Testing Machine (HOUNSFIELD, H25KS).

\section{Graft Co-polymerization of Binary Vinyl Monomer} Mixtures onto Flax Fibers under the Influence of Microwave Radiations

Flax fibers $(0.5 \mathrm{gm})$ were immersed in $100 \mathrm{~mL}$ of distilled water for $24 \mathrm{~h}$ prior to their grafting under the influence of microwave radiations. A definite ratio of FAS- $\mathrm{H}_{2} \mathrm{O}_{2}$ and a known amount of binary monomers were added to the reaction mixture. The reaction mixture was stirred and transferred to microwave oven at $210 \mathrm{~W}$ microwave power $\left(60^{\circ} \mathrm{C}\right)$ for a definite time interval. Microwave technology uses electromagnetic waves, which passes through material and causes its molecules to oscillate. Micro-wave energy is not observed by non-polar materials to any degree while polar water molecules held within a polymer matrix do absorb energy very proficiently, thus becoming heated. ${ }^{12}$ The graft copolymer was Soxhlet extracted with acetone for about 5-6h so as to remove homopolymer. Further, the traces of homopolymer were separated from graft copolymer by stirring the graft copolymer in acetone for about $24 \mathrm{~h}$ using magnetic stirrer. Graft co-polymers obtained were dried in oven at $50^{\circ} \mathrm{C}$ till constant weight was obtained. The percentage grafting $\left(\mathrm{P}_{\mathrm{g}}\right)$ was calculated as follows:

$$
\mathrm{P}_{\mathrm{g}}=\frac{\mathrm{W}_{2}-\mathrm{W}_{1}}{\mathrm{~W}_{1}} \times 100
$$

Where $\mathrm{W}_{1}$ and $\mathrm{W}_{2}$ are the weights of raw flax and grafted flax, respectively.

\section{Moisture Absorbance Behaviour and Fiber Strength of Graft Co-polymers}

Moisture absorbance at different humidity levels of the grafted and ungrafted samples was carried-out as per the methods reported earlier. ${ }^{31,32}$ Fiber strength was measured with fiber bundle strength tester (Stelometer). Known weight of fibers bundle was put in Stelometer and the total strength (gms/tex) required to break the fibers was measured and calculated as follows:

$$
\begin{aligned}
& \text { Strength }(\mathrm{Kg} / \mathrm{mg})=\frac{\text { Total strength of fibers in } \mathrm{Kg}}{\text { Total weight of fibers in } \mathrm{mg}} \\
& \text { Strength } \quad(\mathrm{gms} / \text { tex })=\text { Strength } \quad(\mathrm{Kg} / \mathrm{mg}) \times 15.0 \\
& \text { (constant factor) } \\
& \text { Actual Strength }(\mathrm{gms} / \mathrm{tex})=\text { Strength }(\mathrm{gms} / \mathrm{tex}) \times \\
& \text { Humidity correction factor } \\
& \text { Whereas Humidity correction factor at } \mathrm{RH} 53 \% \text { is } \\
& 1.0756
\end{aligned}
$$




\section{Preparation of Composites}

A definite amount of phenol-formaldehyde resin was thoroughly mixed with fibers (10:0.5 w/w). After thorough mixing of the fibers and resin, the mixture was poured in molds. The surfaces of molds were coated on the inside with oleic acid to avoid adhesion of the mixture and to allow easy removal of the composites. The whole assembly was then placed inside the hot press and cured at $90{ }^{\circ} \mathrm{C}$ and a pressure of $10 \mathrm{Kg} / \mathrm{cm}^{2}$ for $5 \mathrm{~h}$. Composites thus prepared were subjected for the evaluation of different mechanical properties. The numbers of specimen used for the determination of mechanical properties were three and the tests were conducted at ambient laboratory conditions.

\section{Wear Test}

Wear resistance of composites was carried-out as per ASTM D 3702 on DUCOM make machine. Wear resistance was conducted against hardened steel disc having hardness of $60 \mathrm{HRC}$ and roughness Ra: 0.5 $\mu \mathrm{m}$. Counter surface was polished using emery paper and cleaned with acetone before each sliding test. Samples $(3 \mathrm{~cm})$ for wear test were held against rotating counter surface at different speeds (100-600 RPM) and normal loads (1-4 Kg). Each test was conducted for $5 \mathrm{~min}$ of sliding. Loss of weight was used as a measure of wear.

\section{Tensile Strength Test}

Testing of composites for tensile strength was done as per ASTM D 3039. The composite sample of $8 \mathrm{~cm}$ length was clamped between two jaws of the Universal Testing Machine. Each end of the jaws covered $2 \mathrm{~cm}$ of the sample. Rest of the $4 \mathrm{~cm}$ sample was used to study the tensile behaviour. Readings for force and extension were set at zero. The tests were conducted at constant strain rate of order of $5 \mathrm{~mm}$ / min. Tensile stress was applied till the failure of the sample and the load-extension curve was obtained.

\section{Compressive Strength Test}

Compressive strength of the composites was studied by using the procedure described in ASTM D 3410. Composite sample of $4 \mathrm{~cm}$ was held between two platforms and the strain rate was fixed at $2 \mathrm{~mm}$ per minute. The compression stress was applied till the failure of the sample. Total compression per unit force was noted.

\section{Modulus of Rupture and Modulus of Elasticity}

MOR and MOE were determined according to ASTM D 790 in a universal testing machine and were calculated by using the following equations:

$$
\begin{aligned}
\mathrm{MOR} & =\frac{3 \mathrm{PL}}{2 \mathrm{bd}^{2}} \mathrm{~N} / \mathrm{mm}^{2} \\
\mathrm{MOE} & =\frac{\mathrm{P}_{1} \mathrm{~L}^{3}}{4 \mathrm{bd}^{3} \mathrm{y}} \mathrm{N} / \mathrm{mm}^{2}
\end{aligned}
$$

Where $\mathrm{P}=$ peak load, $\mathrm{L}=$ length of sample, $\mathrm{b}=$ width of the sample, $d=$ thickness of the sample, $\mathrm{P}_{1}=$ load at the limit of proportionality and $\mathrm{y}=$ rate of bending.

\section{Stress at the Limit of Proportionality}

Stress at the limit of proportionality was calculated by using the following equation:

$$
\mathrm{SP}=\frac{3 \mathrm{P}_{1} \mathrm{~L}}{2 \mathrm{bd}^{2}} \mathrm{~N} / \mathrm{mm}^{2}
$$

Where $\mathrm{P}_{1}=$ load at the limit of proportionality, $\mathrm{L}=$ length of sample, $\mathrm{b}=$ width of the sample and $\mathrm{d}=$ thickness of the sample.

\section{RESULTS AND DISCUSSION}

$\mathrm{C}_{2}, \mathrm{C}_{3}$ and $\mathrm{C}_{6}$ hydroxyls and the $\mathrm{C}-\mathrm{H}$ groups are the active cites for grafting in cellulosics. The grafting onto flax fibers in presence of FAS- $\mathrm{H}_{2} \mathrm{O}_{2}$ (Fenton's reagent) as initiator is supposed to take place as per the mechanism proposed by Misra et al. ${ }^{33}$ The mechanism for the grafting of flax fibers by vinyl monomers in presence of Fenton's reagent is as follows:

$$
\begin{aligned}
& \mathrm{Fe}^{2+}+\mathrm{H}-\mathrm{O}-\mathrm{O}-\mathrm{H} \longrightarrow \mathrm{OH}^{*}+\mathrm{Fe}^{3+}+\mathrm{OH}^{-} \\
& \mathrm{OH}^{*}+\mathrm{M} \longrightarrow \mathrm{OH}-\mathrm{M}^{*} \stackrel{\mathrm{nM}}{\longrightarrow} \mathrm{OH}-(\mathrm{M})_{\mathrm{n}+1}^{*} \\
& \mathrm{OH}^{*}+\mathrm{Flax}-\mathrm{H} \longrightarrow \text { Flax }^{*}+\mathrm{H}_{2} \mathrm{O} \\
& \mathrm{OH}-(\mathrm{M})_{\mathrm{n}+1}^{*}+\mathrm{Flax}-\mathrm{H} \longrightarrow \text { Flax }^{*}+\mathrm{OH}-(\mathrm{M})_{\mathrm{n}+1}-\mathrm{H} \\
& \text { Flax }^{*}+\mathrm{M} \longrightarrow \text { Flax}-\mathrm{M}^{*} \stackrel{\mathrm{nM}}{\longrightarrow} \text { Flax }-(\mathrm{M})_{\mathrm{n}+1}^{*} \\
& \text { Flax }-(\mathrm{M})_{\mathrm{n}+1}^{*}+\mathrm{OH}^{*} \longrightarrow \text { Flax-}-(\mathrm{M})_{\mathrm{n}+1}-\mathrm{OH} \\
& \text { Flax }-(\mathrm{M})_{\mathrm{n}+1}^{*}+\mathrm{Fe}^{3+} \longrightarrow \text { Flax }-(\mathrm{M})_{\mathrm{n}+1}+\mathrm{Fe}^{2+}
\end{aligned}
$$

Where $\mathrm{M}$ denotes the monomer.

On the basis of the above mechanism, reaction sites on the backbone polymer can be generated by the reaction between $\mathrm{OH}^{*}$ and flax fibers (3). As is clear from step (1), the formation of hydroxyl free radicals $\left(\mathrm{OH}^{*}\right)$ occurs by the reaction between $\mathrm{Fe}^{+2}$ and $\mathrm{H}_{2} \mathrm{O}_{2}$. The $\mathrm{OH}^{*}$ initiate the polymerization reaction to produce the growing polymeric chains (3) which can attack the active sites of polymeric back-bone to give the graft co-polymers (5). Alternatively, the growing polymeric chains can lead to the formation of homo polymer (2). However, the abstraction of hydrogen atom from main back-bone through step (3) is unlikely as the concentration of Fenton's reagent is very small. Therefore, hydroxyl free radicals will prefer to interact with vinyl monomers thereby giving grow- 
ing polymeric chain which in turn creates sites on flax back-bone by hydrogen abstraction (4). Termination of various active species in the reaction mixture may take place by recombination step (6) and by transfer process (7). The concentration of ferric ions $\left(\mathrm{Fe}^{+3}\right)$ in the reaction mixture plays an important role in getting the percentage grafting as it is directly involved in the termination of the reaction.

MWR technique reduces the extent of physicochemical stresses to which the fibers are exposed during the conventional techniques of grafting and it uses electromagnetic waves, which passes through material and causes its molecules to oscillate. Micro-wave energy is not observed by non-polar materials to any degree while polar water molecules held within a polymer matrix do absorb energy very proficiently, thus becoming heated. ${ }^{12}$

\section{Optimization of Various Reaction Parameters}

Optimized reaction conditions for getting maximum graft yield were: MMA $\left(1.96 \times 10^{-3} \mathrm{~mol} \mathrm{~L}^{-1}\right)$; FAS- $\mathrm{H}_{2} \mathrm{O}_{2}$ (molar ratio), 1:6; time (min.), 30 and $\mathrm{pH}, 7.0$.

As evident from Figure $1, \mathrm{P}_{\mathrm{g}}$ increases with increase in monomer concentration and after reaching the maximum value $(24.64 \%)$, further increase in monomer concentration decreases the graft yield which is due to the predomination of homo-polymerization over graft co-polymerization. Moreover, increased viscosity of the reaction medium with homo-polymerization creates hindrance in the path of the free radicals in reaching the active sites, thereby resulting in less graft yield..$^{31,32}$

FAS- $\mathrm{H}_{2} \mathrm{O}_{2}$ molar ratio plays an important role in deciding the graft yield (Figure 2). Maximum grafting has been observed at 1:6 molar ratio, further increase in molar ratio resulted in decreased the graft yield which is due to the fact that at higher concentration more $\mathrm{Fe}^{3+}$ ions are produced which act as the chain terminer. ${ }^{33}$

$\mathrm{P}_{\mathrm{g}}$ has been found to increase with increase in reaction time, but after 30 minutes, a decline in $\mathrm{P}_{\mathrm{g}}$ has

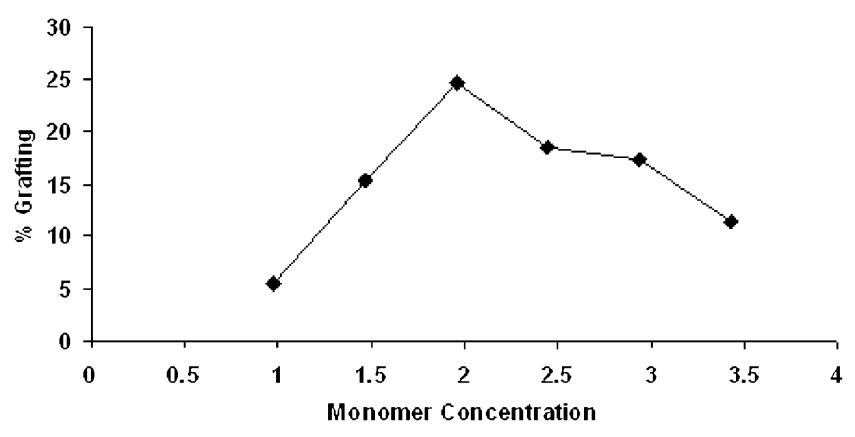

Figure 1. Effect of MMA concentration on \% grafting (Time $=30 \mathrm{~min} ; \mathrm{FAS}: \mathrm{H}_{2} \mathrm{O}_{2}=1.0: 6.0 ; \mathrm{pH}=7.0$ ).

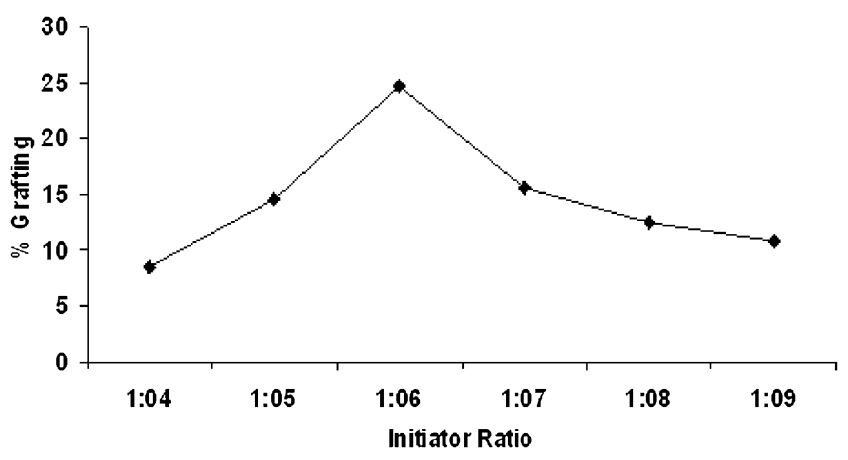

Figure 2. Effect of $\mathrm{FAS}-\mathrm{H}_{2} \mathrm{O}_{2}$ ratio on $\%$ grafting (Time $=$ 30 min; $\mathrm{MMA}=1.96 \times 10^{-3} \mathrm{~mol} \mathrm{~L}^{-1} ; \mathrm{pH}=7.0$ ).

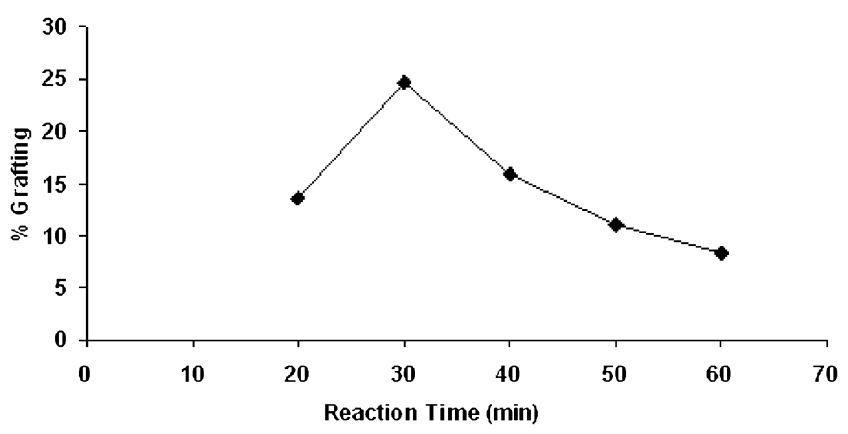

Figure 3. Effect of reaction time on $\%$ grafting $(\mathrm{MMA}=$ $1.96 \times 10^{-3} \mathrm{~mol} \mathrm{~L}^{-1} ; \mathrm{FAS}: \mathrm{H}_{2} \mathrm{O}_{2}=1.0: 6.0 ; \mathrm{pH}=7.0$ ).

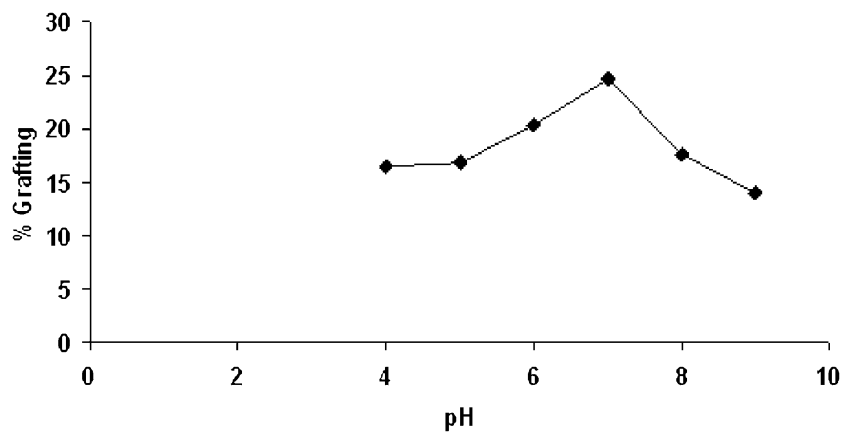

Figure 4. Effect of $\mathrm{pH}$ on $\%$ grafting (Time $=30 \mathrm{~min}$; FAS: $\mathrm{H}_{2} \mathrm{O}_{2}=1.0: 6.0 ;$ MMA $\left.=1.96 \times 10^{-3} \mathrm{~mol} \mathrm{~L}^{-1}\right)$.

been observed (Figure 3). This is due to the settingup of various hydrogen abstraction reactions and increase in viscosity of the medium due to homo-polymerization. $\mathrm{P}_{\mathrm{g}}$ has been found to increase with increase in $\mathrm{pH}$ of the reaction medium till $7.0 \mathrm{pH}$. Further increase in $\mathrm{pH}$ resulted in decreased $\mathrm{P}_{\mathrm{g}}$ (Figure 4). This is probably due to decrease in concentration of free radicals as the $\mathrm{OH}$ ions act as the chain terminer as shown below: ${ }^{31}$

$$
\text { Flax }-(\mathrm{M})_{\mathrm{n}+1}^{*}+\mathrm{OH}^{*} \rightarrow \text { Flax }-(\mathrm{M})_{\mathrm{n}+1}-\mathrm{OH}
$$

Effect of Concentration of Binary Monomer Mixtures on Percent Grafting

Graft copolymerization of binary vinyl monomer 
mixture such as MMA/EA, MMA/AN and MMA/ $\mathrm{AA}$ on to flax fibers under the influence of microwave radiations using MMA $\left(1.96 \times 10^{-3} \mathrm{~mol} \mathrm{~L}^{-1}\right)$ as principal monomer showed $51.2 \%\left(\mathrm{EA}=2.3 \times 10^{-3} \mathrm{~mol}\right.$ $\left.\mathrm{L}^{-1}\right), \quad 17.8 \% \quad\left(\mathrm{AN}=2.27 \times 10^{-3} \mathrm{~mol} \mathrm{~L}^{-1}\right), \quad 12.08 \%$ $\left(\mathrm{AA}=2.91 \times 10^{-3} \mathrm{~mol} \mathrm{~L}^{-1}\right)$ maximum grafting, respectively (Figures $5-7$ ).

In case of graft copolymerization of binary vinyl monomer mixtures such as MMA/EA and MMA/ AN onto flax fibers, a high percent graft yield has been obtained which is due to the presence of strong acceptor monomer in the binary mixture MMA/EA and MMA/AN. A low percent graft yield has been obtained in case of binary mixture MMA/AA, which is due to the fact that AA is more associated with water

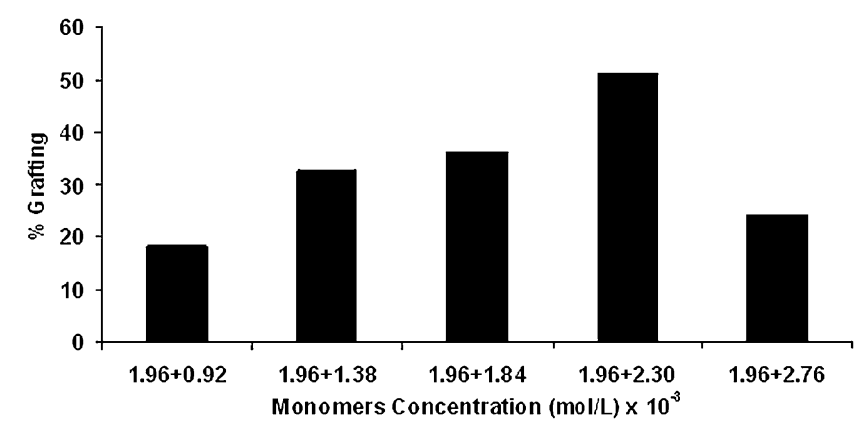

Figure 5. Effect of MMA/EA concentrations on \% grafting under optimum reaction conditions.

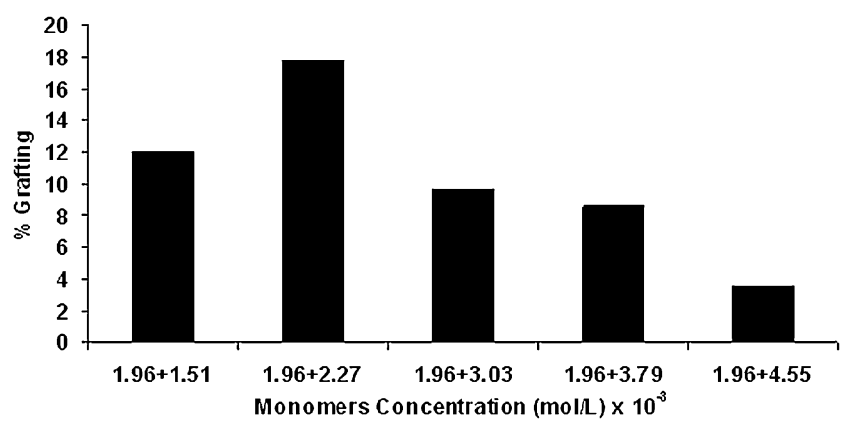

Figure 6. Effect of MMA/AN concentrations on \% grafting under optimum reaction conditions.

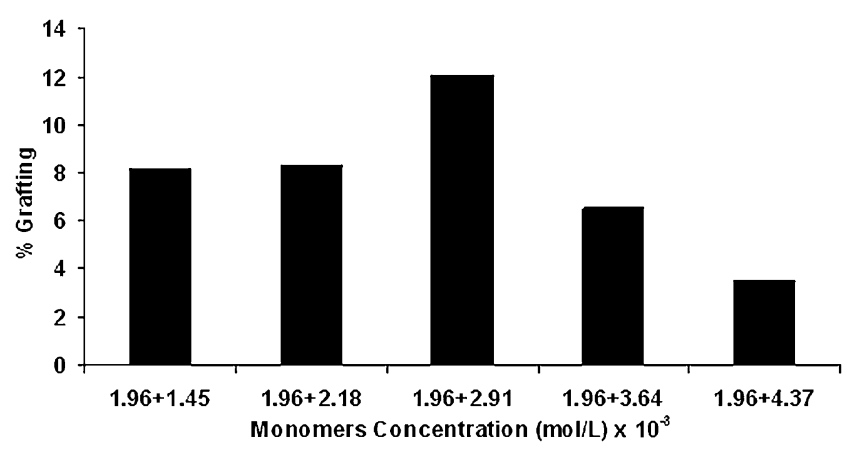

Figure 7. Effect of MMA/AA concentrations on \% grafting under optimum reaction conditions. thereby resulting in decreased free radical sites and hence resulted a low graft yield.

\section{Characterization of Graft Co-polymers}

IR spectrum of raw flax fibers showed a broad peak at $3420 \mathrm{~cm}^{-1}$ which was due to bonded $-\mathrm{OH}$ groups and at $2925.5 \mathrm{~cm}^{-1}, 1458.6 \mathrm{~cm}^{-1}$ and $1055.87 \mathrm{~cm}^{-1}$ arising from $-\mathrm{CH}_{2}, \mathrm{C}-\mathrm{C}$ and $\mathrm{C}-\mathrm{O}$ stretching, respectively. However, in case of Flax-g-poly (MMA/EA), Flax-g-poly (MMA/AN) and Flax-g-poly (MMA/ AA) additional peaks at $1720 \mathrm{~cm}^{-1}$ because of $>\mathrm{C}=\mathrm{O}$ of MMA and at $1780 \mathrm{~cm}^{-1}, 2250 \mathrm{~cm}^{-1}$ and $1695 \mathrm{~cm}^{-1}$ due to $-\mathrm{COOC}_{2} \mathrm{H}_{5},-\mathrm{C}=\mathrm{N}$ and $>\mathrm{C}=\mathrm{O}$ of $-\mathrm{COOH}$, respectively, have been observed. Peak due to $-\mathrm{OH}$ of $-\mathrm{COOH}$ has been observed at $2695 \mathrm{~cm}^{-1}$.

A clear cut distinction between scanning electron micrographs of raw flax and its graft co-polymers, Flax-g-poly (MMA/EA), Flax-g-poly (MMA/AN) and Flax-g-poly (MMA/AA) has been observed. (Figures 8, 9, 10 and 11)

\section{Thermal Behaviour of Graft Co-polymers}

Thermo-gravimetric analysis (TGA) is an important technique to measure the physical properties of a sub-

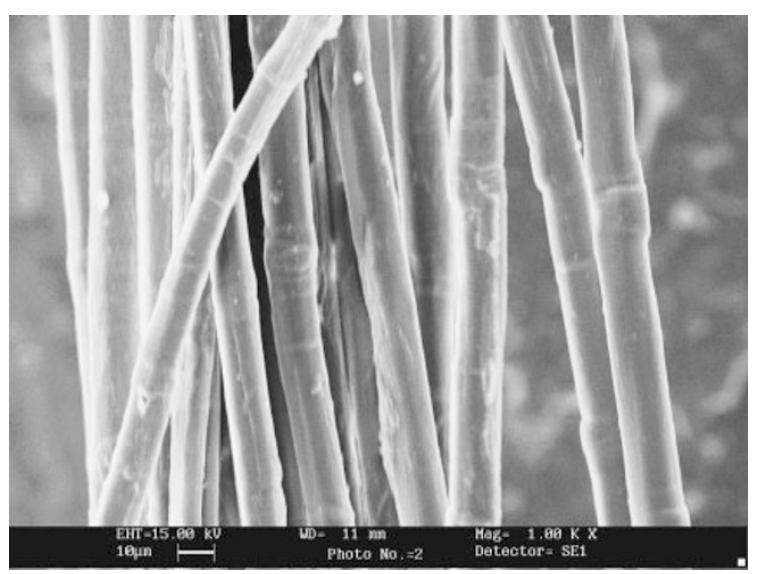

Figure 8. SEM of Raw Flax.

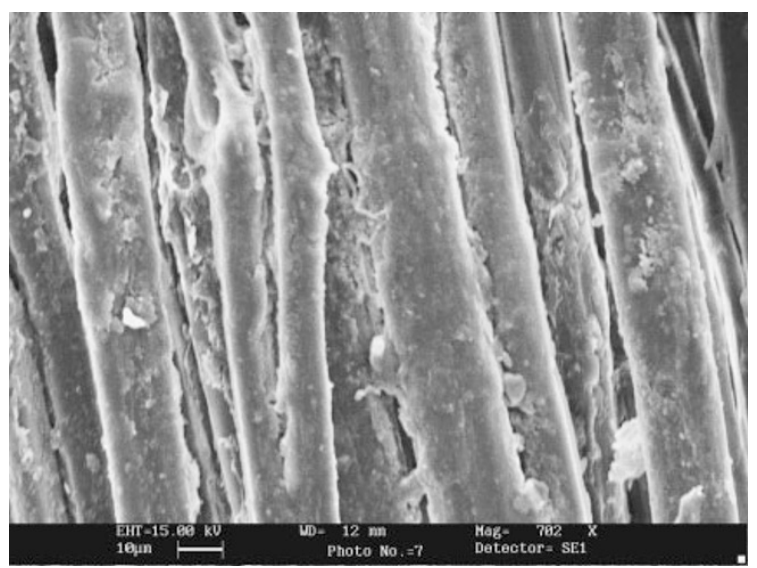

Figure 9. SEM of Flax-g-poly (MMA/EA). 


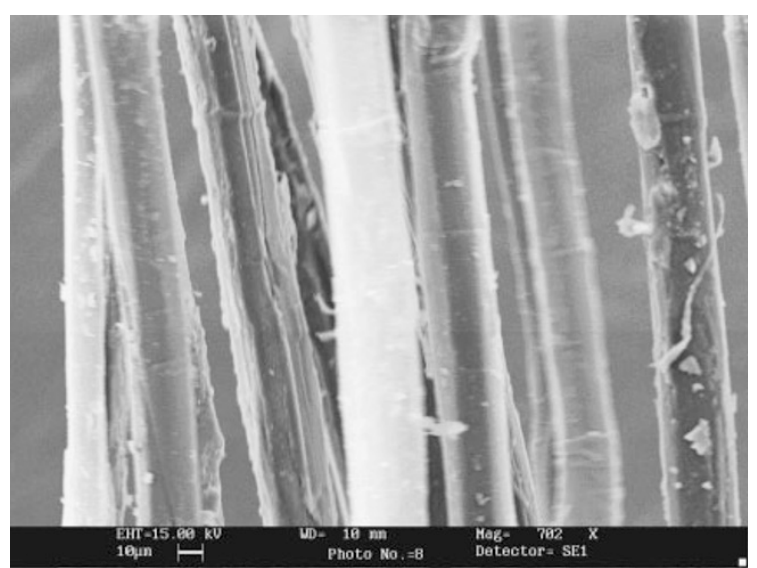

Figure 10. SEM of Flax-g-poly (MMA/AN).

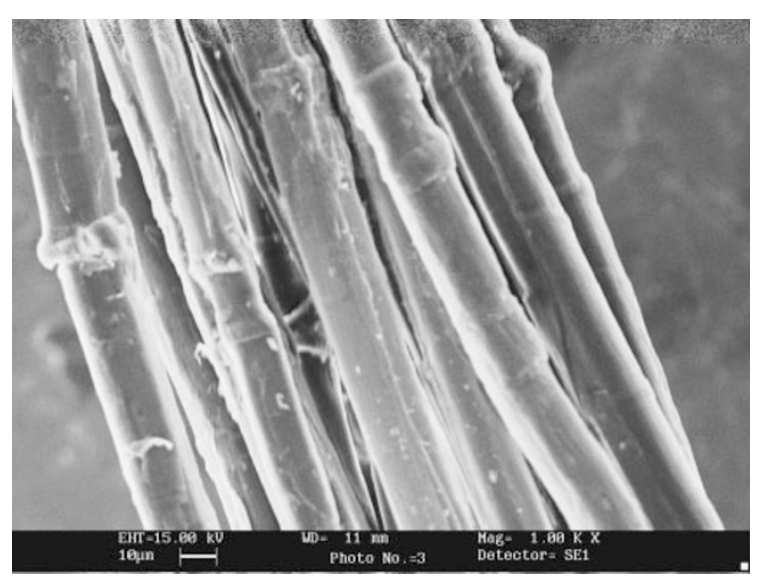

Figure 11. SEM of Flax-g-poly (MMA/AA).

stance and its reaction products as a function of temperature whilst the substance is subjected to a controlled temperature program. ${ }^{34}$ On the other hand, Differential thermal analysis (DTA) is important to identify polymers, to generate phase diagram and for phase transition studies. It helps to determine melting and decomposition of organic compounds. ${ }^{35}$

Thermal transition for a polymer often ranges because even a pure polymer is a mixture of homologs and not a single chemical entity.

Thermo-gravimetric analysis of raw flax fibers and graft co-polymers were carried out as a function of weight loss versus temperature. The results of TGA have been depicted in Table I. It has been found that initial and final decomposition temperatures of raw flax fiber were $279.9^{\circ} \mathrm{C}$ and $489.1^{\circ} \mathrm{C}$, respectively. Whereas in case of Flax-g-poly(MMA/EA), Flax-gpoly(MMA/AN) and Flax-g-poly(MMA/AA), initial decomposition temperatures are $316.1^{\circ} \mathrm{C}, 314.3^{\circ} \mathrm{C}$ and $241.6^{\circ} \mathrm{C}$, respectively and final decomposition temperatures are $415.1{ }^{\circ} \mathrm{C}, 449.2^{\circ} \mathrm{C}$ and $495.7^{\circ} \mathrm{C}$, respectively. In case of Flax-g-poly(MMA/EA) and Flax-g-poly(MMA/AN) initial decomposition tem-
Table I.

\begin{tabular}{|c|c|c|c|c|c|c|}
\hline $\begin{array}{l}\text { Sr. } \\
\text { No. }\end{array}$ & Sample & $\begin{array}{l}\text { IDT } \\
\left({ }^{\circ} \mathrm{C}\right)\end{array}$ & $\begin{array}{c}\% \mathrm{Wt} . \\
\text { Loss }\end{array}$ & $\begin{array}{l}\text { FDT } \\
\left({ }^{\circ} \mathrm{C}\right)\end{array}$ & $\begin{array}{c}\% \mathrm{Wt} . \\
\text { Loss }\end{array}$ & $\begin{array}{c}\text { Final } \\
\text { Residue } \\
(\%)\end{array}$ \\
\hline 1. & Raw Flax & 279.9 & 16 & 489.1 & 72 & 12 \\
\hline 2. & Flax-g-poly(MMA/EA) & 316.1 & 1 & 415.1 & 52 & 47 \\
\hline 3. & Flax-g-poly(MMA/AN) & 314.2 & 2 & 449.2 & 41 & 57 \\
\hline 4. & Flax-g-poly(MMA/AA) & 241.6 & 11 & 495.7 & 87 & 2 \\
\hline
\end{tabular}

peratures are higher as compared to those of raw flax fibers and Flax-g-poly(MMA/AA). However, in case of Flax-g-poly(MMA/AA), thermal stability is not altered as much by grafting process. Flax-g-poly(MMA/AA) has been found to show higher final decomposition temperature. This is due to the less percent grafting with MMA/AA, therefore, fewer disturbances in crystal structure of the fibers.

TGA results have been supported by Differential thermal analysis (DTA) studies. DTA of raw flax fiber shows exothermic peaks at $325.3^{\circ} \mathrm{C}(13.8 \mu \mathrm{V})$ and there has been a continuous exothermic combustion of the sample at furnace temperature in presence of atmospheric oxygen. This peak shows the disturbance in H-bonded amorphous region. Another sharp exothermic peak has been observed at $455.3{ }^{\circ} \mathrm{C}(38.9$ $\mu \mathrm{V})$, which indicates the complete break down of the crystalline region at this temperature. However, in case of Flax-g-poly(MMA/EA) and Flax-g-poly(MMA/AN), exothermic peaks at $374.7^{\circ} \mathrm{C}(47.1 \mu \mathrm{V})$ and $347.0^{\circ} \mathrm{C}(28.1 \mu \mathrm{V}) / 408.2^{\circ} \mathrm{C}(31.8 \mu \mathrm{V})$ have been observed, respectively (Table II). Flax-g-poly(MMA/ AA) has been found to exhibit a sharp exothermic peak at $435.1{ }^{\circ} \mathrm{C}(48.9 \mu \mathrm{V})$ (Table II). With increase in percentage of grafting, the original crystal lattice of the fibers gets disturbed, which results in the lower final decomposition temperature of the graft co-polymers. Thus it has been observed that there exists a direct correlation with percentage of grafting and crystallinity.

\section{Moisture Absorbance Behaviour}

It is evident from Figures 12-14 that moisture absorbance decreases with increase in $\mathrm{P}_{\mathrm{g}}$. Cellulosic

Table II.

\begin{tabular}{ccc}
\hline $\begin{array}{c}\text { Sr. } \\
\text { No. }\end{array}$ & Sample & $\begin{array}{c}\text { Exothermic peaks at } \\
\text { temperature }(\mu \mathrm{V})\end{array}$ \\
\hline 1. & Raw Flax & $325.3^{\circ} \mathrm{C}(13.8)$ \\
& & $455.3^{\circ} \mathrm{C}(38.9)$ \\
2. & Flax-g-poly(MMA/EA) & $374.7^{\circ} \mathrm{C}(47.1)$ \\
3. & Flax-g-poly(MMA/AN) & $347.0^{\circ} \mathrm{C}(28.1)$ \\
& & $408.2^{\circ} \mathrm{C}(31.8)$ \\
4. & Flax-g-poly(MMA/AA) & $435.1^{\circ} \mathrm{C}(48.9)$ \\
\hline
\end{tabular}




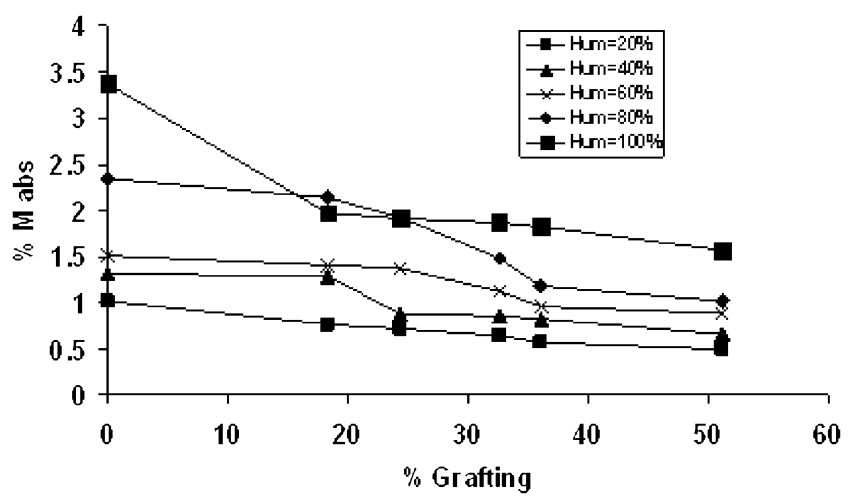

Figure 12. Effect of $\%$ grafting of MMA/EA onto flax fibers on moisture absorbance behaviour.

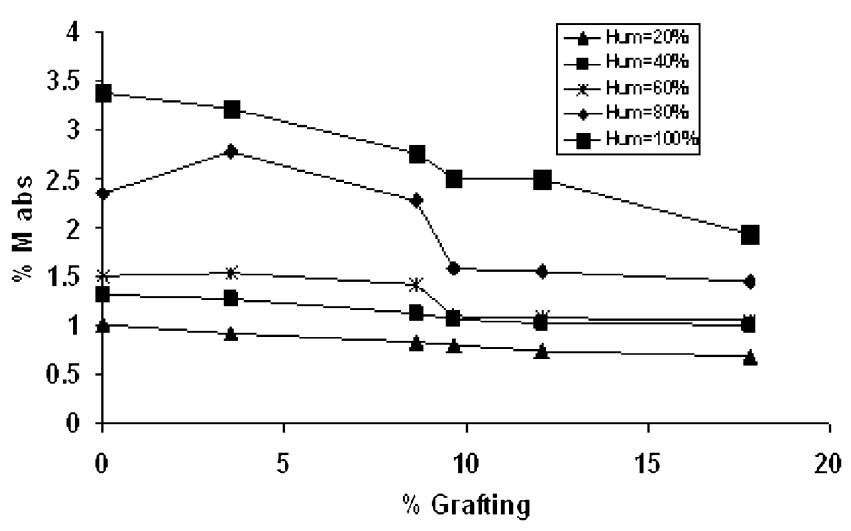

Figure 13. Effect of $\%$ grafting of MMA/AN onto flax fibers on moisture absorbance behaviour.

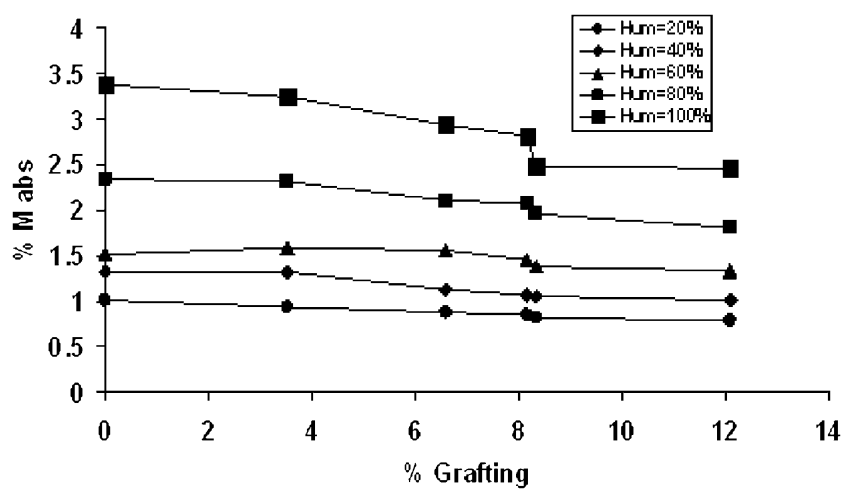

Figure 14. Effect of $\%$ grafting of MMA/AA onto flax fibers on moisture absorbance behaviour.

fibers contain active groups like $-\mathrm{OH}$ and $-\mathrm{CH}_{2} \mathrm{OH}$. These groups have got high affinity towards moisture. Moreover, these are the groups on the backbone polymer where the grafting of the polymer chains takes place and are known as active sites. On grafting most of these active sites vulnerable to moisture absorbance, get blocked with the incorporation of poly(MMA/EA), poly(MMA/AN) and poly(MMA/AA) chains. Thus with increase in percentage grafting
Table III.

\begin{tabular}{lcc}
\hline Sample Code & \% Grafting & $\begin{array}{c}\text { Fiber Strength } \\
\text { (gms/tex) }\end{array}$ \\
\hline Raw Flax & - & 28.84 \\
Flax-g-poly(MMA/EA) & 51.20 & 37.58 \\
Flax-g-poly(MMA/AN) & 17.80 & 36.90 \\
Flax-g-poly(MMA/AA) & 12.08 & 57.59 \\
\hline
\end{tabular}

Table IV.

\begin{tabular}{lcccc}
\hline \multirow{2}{*}{ Sample Code } & \multicolumn{4}{c}{ Wear Resistance $\left(\mathrm{gm} / \mathrm{m} \times 10^{-4}\right)$} \\
\cline { 2 - 5 } & $1 \mathrm{Kg}$ & $2 \mathrm{Kg}$ & $3 \mathrm{Kg}$ & $4 \mathrm{Kg}$ \\
\hline Phenol-formaldehyde & 18 & 34 & 56 & 77 \\
Raw Flax reinforcement & 10 & 14 & 17 & 21 \\
$\begin{array}{l}\text { Flax-g-poly(MMA/EA) } \\
\text { reinforcement }\end{array}$ & 8 & 11 & 16 & 20 \\
$\begin{array}{l}\text { Flax-g-poly(MMA/AN) } \\
\text { reinforcement }\end{array}$ & 11 & 16 & 22 & 28 \\
$\begin{array}{l}\text { Flax-g-poly(MMA/AA) } \\
\text { reinforcement }\end{array}$ & 6 & 8 & 11 & 13 \\
\hline
\end{tabular}

moisture absorbance decreases and fibers becomes more and more moisture retardant. ${ }^{31,32}$

\section{Fiber Strength}

It has been observed that graft copolymers showed more fiber strength in comparison to raw flax fibers. Optimum reaction time for getting maximum graft yield is quite less, so grafting has resulted in less surface flaws and the crystal lattice of the fibers is not disturbed very much which leads to better fiber strength of graft co-polymers ${ }^{12,36}$ (Table III).

Mechanical Properties of the Raw Flax and Flax-gcopolymer Reinforced Phenol-Formaldehyde Composites

Wear Test. It is evident from Table IV that wear resistance is maximum with Flax-poly(MMA/AA) reinforcement followed by Flax-poly(MMA/EA), raw flax, Flax-poly(MMA/AN) and phenol-formaldehyde matrix. Loss of material in these samples is due to abrasion and frictional heat generated due to sliding, which enhances further on increasing the load. ${ }^{23-27}$

\section{Tensile Strength}

It has been observed that composites reinforced with Flax-g-poly(MMA/EA) showed better tensile strength and can bear load upto $225 \mathrm{~N}$ with extension of $3.28 \mathrm{~mm}$. Composites reinforced with raw flax, Flax-g-poly(MMA/AA) and Flax-g-poly(MMA/AN) can bear load upto $150 \mathrm{~N}$ with extension of 2.17 $\mathrm{mm}, 2.23 \mathrm{~mm}$ and $2.37 \mathrm{~mm}$, respectively. Phenolformaldehyde matrix gets failure at $75 \mathrm{~N}$ with extension of $1.88 \mathrm{~mm}^{23-27}$ (Table V). 
Table V.

\begin{tabular}{lcc}
\hline Sample Code & $\begin{array}{c}\text { Tensile } \\
\text { Strength (N) }\end{array}$ & Extension (mm) \\
\hline Phenol-formaldehyde & 75 & 1.88 \\
Raw Flax reinforcement & 150 & 2.17 \\
$\begin{array}{l}\text { Flax-g-poly(MMA/EA) } \\
\text { reinforcement }\end{array}$ & 225 & 3.28 \\
$\begin{array}{l}\text { Flax-g-poly(MMA/AN) } \\
\text { reinforcement }\end{array}$ & 150 & 2.37 \\
$\begin{array}{l}\text { Flax-g-poly(MMA/AA) } \\
\text { reinforcement }\end{array}$ & 150 & 2.23 \\
\hline
\end{tabular}

Table VI.

\begin{tabular}{lcc}
\hline Sample Code & $\begin{array}{c}\text { Compressive } \\
\text { Strength (N) }\end{array}$ & Compression (mm) \\
\hline Phenol-formaldehyde & 200 & 0.62 \\
Raw Flax reinforcement & 400 & 1.18 \\
$\begin{array}{l}\text { Flax-g-poly(MMA/EA) } \\
\text { reinforcement }\end{array}$ & 800 & 1.63 \\
$\begin{array}{l}\text { Flax-g-poly(MMA/AN) } \\
\text { reinforcement }\end{array}$ & 800 & 1.87 \\
$\begin{array}{l}\text { Flax-g-poly(MMA/AA) } \\
\text { reinforcement }\end{array}$ & 1000 & 1.74 \\
\hline
\end{tabular}

\section{Compressive Strength}

As evident from Table VI that composites reinforced with Flax-g-poly(MMA/AA) showed better compressive strength and can bear load upto $1000 \mathrm{~N}$ with compression of $1.74 \mathrm{~mm}$. Composites reinforced with Flax-g-poly(MMA/EA) and Flax-g-poly(MMA/ AN) also showed better compressive strength and can bear load upto $800 \mathrm{~N} / \mathrm{mm}^{2}$ with compression of 1.63 $\mathrm{mm}$ and $1.87 \mathrm{~mm}$, respectively in comparison to composites reinforced with raw flax and phenol-formaldehyde matrix which gets failure at $400 \mathrm{~N}$ and $200 \mathrm{~N}$ with compression of $1.18 \mathrm{~mm}$ and $0.62 \mathrm{~mm}$, respectively. ${ }^{23-27}$

Modulus of Rupture, Modulus of Elasticity and Stress at the Limit of Proportionality

Table VII shows the results of the MOR, MOE and SP for flax fiber and graft co-polymers reinforced composites. MOR for phenol-formaldehyde and composites reinforced with Flax fiber has been found to be 36 and $72 \mathrm{~N} / \mathrm{mm}^{2}$, respectively. Values of MOR were found to be $72 \mathrm{~N} / \mathrm{mm}^{2}, 72 \mathrm{~N} / \mathrm{mm}^{2}$ and $108.0 \mathrm{~N} / \mathrm{mm}^{2}$ for the composites reinforced with Flax-g-poly(MMA/EA), Flax-g-poly(MMA/AN) and Flax-gpoly(MMA/AA), respectively. Maximum and minimum values of MOE were found to be $5295.62 \mathrm{~N} /$ $\mathrm{mm}^{2}$ and $1336.32 \mathrm{~N} / \mathrm{mm}^{2}$ for the composites reinforced with Flax-g-poly(MMA/AA) and PF matrix, respectively. The MOE of flax fiber reinforced composites was found to be $3280.64 \mathrm{~N} / \mathrm{mm}^{2}$. Composites reinforced with Flax-g-poly(MMA/AA) showed max-
Table VII.

\begin{tabular}{|c|c|c|c|c|}
\hline $\begin{array}{l}\text { Sr. } \\
\text { No. }\end{array}$ & Sample & $\begin{array}{c}\mathrm{MOR} \\
\left(\mathrm{N} / \mathrm{mm}^{2}\right)\end{array}$ & $\begin{array}{c}\mathrm{MOE} \\
\left(\mathrm{N} / \mathrm{mm}^{2}\right)\end{array}$ & $\begin{array}{c}\mathrm{SP} \\
\left(\mathrm{N} / \mathrm{mm}^{2}\right)\end{array}$ \\
\hline 1. & Phenol-formaldehyde & 36.0 & 1336.32 & 25.06 \\
\hline 2. & Flax Fibers reinforcement & 72.0 & 3280.64 & 61.51 \\
\hline 3. & $\begin{array}{l}\text { Flax-g-poly(MMA/EA) } \\
\text { reinforcement }\end{array}$ & 72.0 & 3395.58 & 63.68 \\
\hline 4. & $\begin{array}{l}\text { Flax-g-poly(MMA/AN) } \\
\text { reinforcement }\end{array}$ & 72.0 & 3440.13 & 64.50 \\
\hline 5. & $\begin{array}{l}\text { Flax-g-poly(MMA/AA) } \\
\text { reinforcement }\end{array}$ & 108.0 & 5295.62 & 99.29 \\
\hline
\end{tabular}

imum value of SP $\left(99.29 \mathrm{~N} / \mathrm{mm}^{2}\right)$. The minimum value of SP was found in case of PF matrix.

Results showed that reinforcement of Flax-g-copolymers increased the MOR. It was determined that reinforcement of Flax-g-poly(MMA/AA) and other graft copolymers increased the MOE and SP as compared to flax fiber.

\section{CONCLUSION}

Grafting through microwave radiation technique is an effective method for modifying the properties of natural fibers in terms of time consumption. Graft copolymers of flax fibers showed better fiber strength than raw flax. Flax-g-poly(MMA/AA) has been found to show good thermal stability. Composites reinforced with graft co-polymers showed better mechanical properties in comparison to raw flax fibers reinforcement.

\section{REFERENCES}

1. A. Hebeish and J. T. Guthrie, in "The chemistry and Technology of Cellulosic Copolymers," Springer Verlag, Berlin, Heidelberg, Chapter 2, 1981.

2. M. K. Zahran, M. Morsy, and R. I. Mahmoud, J. Appl. Polym. Sci., 91, 1261 (2004).

3. A. Hebeish, M. H. El-Rafie, A. Waly, and A. Z. Moursi, J. Appl. Polym. Sci., 22, 1853 (1978).

4. R. K. Samal, S. C. Satrusallya, and P. K. Sahoo, J. Appl. Polym. Sci., 29, 319 (1984).

5. G. F. Fanta, R. C. Burr, and W. M. Doane, J. Appl. Polym. Sci., 33, 899 (1987).

6. A. Hebeish, N. Y. Abou-Zeid, A. I. Waly, and E. A. El-Alfy, Angew. Makromol. Chem., 70, 87 (1978).

7. R. Y. M. Huang, B. Immergut, E. H. Immergut, and W. H. Rapson, J. Polym. Sci., Part A, 1, 1257 (1963).

8. S. N. Bhattacharyya and D. Maldas, J. Appl. Polym. Sci., 30, 159 (1985).

9. S. Trbojevi-Gobac, M. Vlatkovi, and Z. Mei, J. Appl. Polym. Sci., 24, 1101 (1979).

10. L. Jianqin, Z. Maolin, and H. Hongfei, Radiat. Phys. Chem., 55, 55 (1999).

11. J. T. Guthrie and G. M. Robinson, Polym. Photochem., 3, 
189 (1983).

12. M. Tsukada, S. Islam, T. Arai, A. Boschi, and G. Freddi, Autex Res. J., 5, 40 (2005).

13. M. Tsukada, S. Islam, T. Arai, A. Boschi, and G. Freddi, Int. Nonwovens J., 10, 4 (2001).

14. G. Freddi, M. R. Massafra, S. Beretta, S. Shibata, Y. Gotoh, H. Yasui, and M. Tsukada, J. Appl. Polym. Sci., 60, 1867 (1996).

15. V. Singh, A. Tiwari, D. N. Tripathi, and R. Sanghi, Carbohydr. Polym., 58, 1 (2004).

16. V. Singh, A. Tiwari, D. N. Tripathi, and R. Sanghi, Polymer, 47, 254 (2006).

17. G. R. Lightsey, in "Polymer Application of Renewable Resource Materials,” C. E. Carrahen, Jr., and L. H. Sperling, Ed., Plenum Press, New York, 1983, pp 193-211.

18. T. Nishino, K. Hirao, M. Kotera, K. Nakamae, and H. Inagaki, Compos. Sci. Technol., 63, 1281 (2003).

19. S. V. Joshi, L. T. Drzal, A. K. Mohanty, and S. Arora, Composites Part A, 35, 371 (2004).

20. J. Simon, H. P. Muller, R. Koch, and V. Muller, Polym. Degrad. Stab., 59, 107 (1998).

21. A. C. Karmaker, J. Mater. Sci. Lett., 16, 462 (1997).

22. "Handbook of fillers for plastics," H. S. Katz and J. V. Milewski, Ed., Section VI, Van Nostrand Reinhold, New York, 1987.

23. B. S. Kaith, A. S. Singha, D. K. Dwivedi, S. Kumar, D.
Kumar, and A. Dhemeniya, Int. J. Plast. Tech., 7, 119 (2003).

24. D. K. Dwivedi, A. S. Singha, S. Kumar, and B. S. Kaith, Int. J. Plast. Tech., 8, 299 (2004).

25. A. S. Singha, S. Kumar, and B. S. Kaith, Int. J. Plast. Tech., 9, 427 (2005).

26. B. S. Kaith and S. Kalia, Polym. Compos., In Press.

27. C. Escamilla, J. I. Cauich-Cupul, E. Mendiza'bal, J. E. Puig, H. Va'zquez-Torres, and P. J. Herrera-Franco, Composites Part A, 30, 349 (1999).

28. K. Lenghaus, G. G. H. Qiao, and D. H. Solomon, Polymer, 42, 7523 (2001).

29. A. Zmihorska-Gotfryd, Prog. Org. Coat., 49, 109 (2004).

30. M. Wang, L. Wei, and T. Zhao, Polymer, 46, 9202 (2005).

31. B. S. Kaith, A. S. Singha, S. Kumar, and B. N. Misra, J. Polym. Mater., 22, 425 (2005).

32. B. S. Kaith, A. S. Singha, and S. Kumar, J. Polym. Mater., 20, 195 (2003).

33. B. N. Misra, P. S. Chandel, and R. Dogra, J. Polym. Sci., Polym. Chem. Ed., 16, 1801 (1978).

34. R. C. Mackenzie, Thermochim. Acta, 28, 1 (1979).

35. D. A. Skoog, F. J. Holler, and T. A. Nieman, in "Principles of Inst. Analysis," Thomson Brooks/Cole, CA, 1998, p 804.

36. B. S. Kaith, A. S. Singha, and S. Kalia, Autex Research Journal, 7, 119 (2007). 